Gitation: Pérez-Ruiz, E., MoralesVelázquez, J. V., Cortez-Romero, C., Gallegos-Sánchez, J., \& FraireCordero, S. (2021) Administration of royal jelly in estrus synchronization protocols for wool and hair sheep. Agro Productividad. https://doi.org/10.32854/ agrop.v14i8.2106.

Editor in Chief: Dr. Jorge Cadena Iñiguez

Received: April 14, 2021.

Accepted: August 21, 2021.

Published on-line: October 12, 2021

This work is licensed under a Creative Commons Attribution-NonCommercial 4.0 International license.

\title{
Administration of royal jelly in estrus synchronization protocols for wool and hair sheep
}

\author{
Pérez-Ruiz, Elizabeth ${ }^{1,2}$; Morales-Velázquez, José V.3; Cortez-Romero, César4; Gallegos-Sánchez, \\ Jaime1; Fraire-Cordero, Silvia5* \\ ${ }^{1}$ Colegio de Postgraduados Campus Montecillo. Carretera Federal México-Texcoco, km 36.5, Texcoco, Edo \\ de México, México. \\ 2 Instituto Nacional de Investigaciones Forestales Agrícolas y Pecuarias, Campo Experimental La Campana, \\ km 33.5, Aldama, Chihuahua, México. \\ 3 Instituto Mexicano del Seguro Social, Texcoco, Estado de México, México. \\ 4 Colegio de Postgraduados, Campus San Luis Potosí. Salinas de Hidalgo, San Luis Potosí, México. \\ ${ }^{5}$ CONACyT-Colegio de Postgraduados Campus Campeche. Carretera Haltunchén-Edzná, km 17.5, \\ Champotón, Campeche, México. \\ * Correspondence: frairec@colpos.mx
}

\begin{abstract}
Objective: To assess the most relevant results on the usage of royal jelly in reproductive protocols of wool and hair sheep.

Design/methodology/approach: A review of studies referenced and published in scientific databases regard the livestock sector.

Results: In ewes, administration of "royal jelly" in addition to reproductive management protocols improves the response to estrus synchronization, time of onset and duration of estrus, number of large follicles, ovulatory rate and gestation rate.

Study limitations/implications: Royal jelly is a substance with beneficial effects on reproductive variables in ewes; however, the cost may be a limitation for its incorporation in synchronization protocols. Additionally, it is necessary to clarify the active metabolites that exert the action and the most effective route of administration. Findings/conclusions: Royal jelly can be an alternative incorporated to estrus synchronization programs in ewes to substitute some hormones without decreasing reproductive variables.
\end{abstract}

Key words: Apis mellifera, reproduction, reproductive management, sheep.

\section{INTRODUCTION}

In small ruminant reproductive management, it is possible to reduce the use of exogenous hormones by optimizing the animal's response to the environment and nutrition. These management strategies propose using knowledge and available resources (Delgadillo and Martin, 2015). In the reproductive management of sheep, it is possible to use targeted 
or strategic nutrition (Martin, 2009), with supplements containing bioactive compounds (Delgadillo and Martin, 2015) or modifying metabolic hormone concentrations (Scaramuzzi et al., 2006) to improve reproductive performance (Gutiérrez et al., 2011). In this regard, royal jelly $(\mathrm{RJ})$, produced by the cephalic glands of worker bees (Apis mellifera), can improve reproductive response in different species (Pavel et al., 2011).

With the use of RJ in the reproductive management of wool ewes, positive effects are reported for reproductive variables such as estrus incidence, time of estrus onset, as well as an improvement in the percentage of gestation (Kridli et al., 2003; Husein and Haddad, 2006). Royal jelly administration in hair sheep at different physiological stages shows similar results. The objective of this review is to present some of the results obtained with the application of $\mathrm{RJ}$ in the reproductive management of wool and hair sheep.

\section{Royal jelly in estrus synchronization protocols in wool ewes}

Administration of $\mathrm{RJ}\left(250 \mathrm{mg} \mathrm{d}^{-1}\right)$ orally or intramuscularly to Awassi ewes for $12 \mathrm{~d}$ (during the estrus synchronization protocol), shortened the time of estrus onset $(31 \pm 2.6$ h), compared to ewes in the control group $(45 \pm 5.4 \mathrm{~h})$, and increased the number of ewes responding to synchronization to $80 \%$, to $40 \%$ in the control group (Husein and Kridli, 2002). Kridli et al. (2003) report that administration of $250 \mathrm{~g} \mathrm{RJ} \mathrm{d}^{-1}$, orally for $12 \mathrm{~d}$, increased the percentage of ewes with signs of estrus compared to the control group (80 vs. $40 \%$ ), in addition, the percentage of pregnant ewes also improved with $\mathrm{RJ}$ administration (60 vs. 20\%).

The application of three different doses of $\mathrm{RJ}\left(250,500,750 \mathrm{mg} \mathrm{d}^{-1}\right)$ orally, during an estrus synchronization protocol (12 d), showed that there were no differences among the three different doses for the variable estrus onset. The 500 and $750 \mathrm{mg}$ RJ doses improved the estrus onset (49.6 \pm 7 and $49.0 \pm 8 \mathrm{~h}$ ), compared to ewes that did not receive $\mathrm{RJ}(59.6 \pm 7$ h). The results obtained with the 500 and $750 \mathrm{mg}$ RJ doses compared to the administration of a $600 \mathrm{IU}$ dose of eCG showed no differences for the onset of estrus, percentage of gestation and prolificacy variables (Kridli and Al-Khetib, 2006).

When comparing the response of an estrus synchronization protocol in Awassi ewes, with the application of 12 doses of RJ of $400 \mathrm{mg} \mathrm{d}^{-1}$ (orally), or the application of 500 IU of eCG, similar results were reported between both treatments for the response to synchronization, fertility or prolificacy variables, so it is proposed that RJ is an alternative for the use of eCG in wool ewes (Husein and Haddad, 2006).

Mostafa et al. (2008) found that RJ application for $21 \mathrm{~d}$ (RJ treatment initiated at 15 days postpartum) reduced days between lambing and first estrus (33.30 0.57 vs. $44.80 \pm 0.4$ d) in Ossimi ewes. Estrus duration increased by $10 \mathrm{~h}$ on average in the RJ-treated ewes ( $41 \pm 0.42$ vs. $31 \pm 0.31 \mathrm{~h}$ ), possibly because RJ increases the number of growing follicles, as well as plasma estradiol levels, necessary for the ewe to show signs of estrus.

\section{Royal jelly in estrus synchronization protocols in hair ewes}

On a reproductive management protocol in which eCG or $\mathrm{RJ}$ was used in hair ewes, a shorter time to the onset of estrus was found in the eCG treated group (21.10 2.34 h), compared to the group treated with RJ (30.95 \pm 1.29 h). Ewes only synchronized with 
progesterone showed signs of estrus at a longer time $(36.78 \pm 2.88 \mathrm{~h})$. The RJ or eCG administration did not modify the ovulation rate and percentage of gestation variables (Pérez et al., 2014).

When researching whether RJ has any direct effect on follicular development, it is reported that the administration of three applications of $500 \mathrm{mg} \mathrm{RJ} \mathrm{d}^{-1}$, intramuscularly, does not modify the number of small, medium and large follicles (similar between control and RJ-treated ewes) (Figure 1). Estrus duration was longer in RJ-treated ewes $(54.7 \pm 2.32$ vs. $47.5 \pm 3.47 \mathrm{~h}$ ) compared to those in the control group (Pérez-Ruiz et $a l ., 2015)$. The effect on estrus duration coincides with that reported by Mostafa et al. (2008) in Ossimi ewes. However, when RJ treatment is increased to seven days (500 $\mathrm{mg} \mathrm{d}^{-1}$ ) and administered intravenously, it is possible to increase the number of large follicles $(>4 \mathrm{~mm})$, shorten the time to estrus onset $(49.08 \pm 2.09 \mathrm{vs} .54 .08 \pm 1.35 \mathrm{~h})$ and increase the ovulation rate $(2.83 \pm 0.16$ vs. $1.83 \pm 0.16)$, in Pelibuey ewes (Sosa-Pérez $e t$ al., 2017).

In a reproductive management protocol excluding hormones, the administration of $1.0 \mathrm{~g} \mathrm{RJ}$ on 30,37, 44 and 51 postpartum days did not shorten the resumption of ovarian activity (evaluated by ultrasonography with the presence of corpora lutea in the ovaries) in Pelibuey ewes (Pérez-Ruiz et al., 2018). In this research, in addition to the application of RJ, the suckling control strategy (30 min twice per day) was evaluated. Upon weaning, socio-sexual stimulation was initiated with the male every $12 \mathrm{~h}$, and the response to estrus was evaluated, which was similar among all ewes. For the variable estrus onset, the RJ did not modify the response, but the suckling control did have a significant effect; in the continuous suckling group, estrus started in less time $\left(3.5 \pm .9\right.$ vs. $\left.7.5 \pm 1.3 \mathrm{~d}^{-1}\right)$ than in the controlled suckling group. Estrus duration was significantly longer in RJ-treated ewes for both suckling modalities. The presentation of silent estrus may be a common problem in postpartum ewes, so the effect of RJ on increasing estrus duration could improve reproductive efficiency by promoting the expression of estrous behavior.
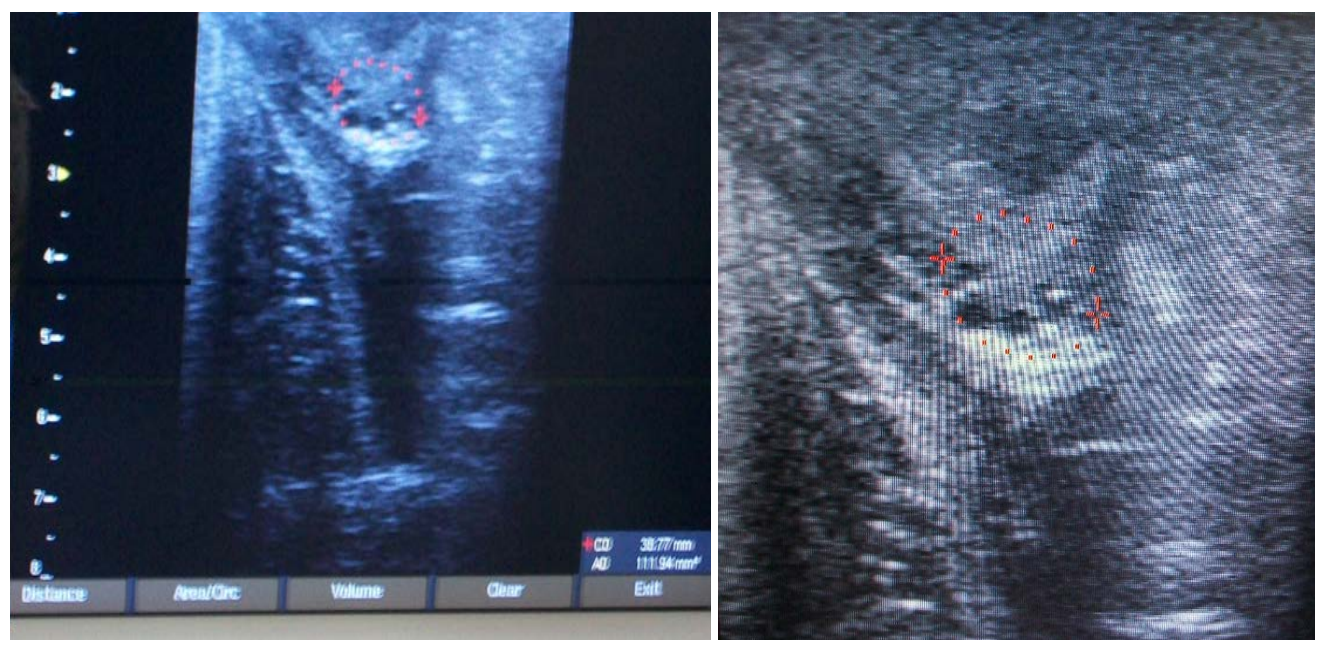

Figure 1. Large follicles $(<5 \mathrm{~mm})$ in hair sheep synchronized with $\mathrm{CIDR}^{\circledR}$ and royal jelly application. 


\section{CONGLUSIONS}

The results obtained by the administration of royal jelly in wool and hair sheep suggest a positive effect of this substance on reproductive variables such as follicular growth, estrus onset, estrus duration, ovulation rate and gestation, so it can be a natural alternative to the use of exogenous hormones, yet more research is needed to identify the metabolites that exert the action, as well as the most effective route of administration.

\section{REFERENGES}

Delgadillo, J.A., Martin, G.B. (2015). Alternative methods for control of reproduction in small ruminants: A focus on the needs of grazing industries. Animal Frontiers, 5(1), 57-65. Doi: 10.2527/af.2015-0009.

Gutiérrez, G.G., Ferraro, S., Martínez, V., Saharrea, A., Cortez, G., Lassala, A., Basurto, H., Hernández, J. (2011). Increasing ovulation quota: More than a matter of energy. Acta Scientiae Veterinariae, 39(1), 305-316.

Husein, M.Q., Haddad, S.G. (2006). A New Approach to Enhance Reproductive Performance in Sheep Using Royal Jelly in Comparison with Equine Chorionic Gonadotropin. Animal Reproduction Science, 93(1-2), 24-33. Doi: 10.1016/j.anireprosci.2005.06.012.

Husein, M.Q., Kridli, R.T. (2002). Reproductive Responses Following Royal Jelly Treatment Administered Orally or Intramuscularly into Progesterone-Treated Awassi Ewes. Animal Reproduction Science, 74(1-2), 45-53. Doi: 10.1016 / s0378-4320 (02) 00165-3

Kridli, R.T., Al-Khetib, S.S. (2006). Reproductive responses in ewes treated with eCG or increasing doses of royal jelly. Animal Reproduction Science, 92(1-2), 75-85. Doi: 10.1016/j.anireprosci.2005.05.021

Kridli, R.T., Husein, M.Q., Humphrey, W.D. (2003). Effect of Royal Jelly and GnRH on the Estrus Synchronization and Pregnancy Rate in Ewes Using Intravaginal Sponges. Small Ruminant Research, 49(1), 25-30. Doi: 10.1016/S0921-4488(03)00057-9

Martin, G.B. (2009). The "Clean, Green and Ethical" Concept in Animal Production. Agrociencia, 13(3),1-7.

Mostafa, A.S., Abd-Allah, S.M., Ali, S.A., Abdel-Azeem, S.N. (2008). Reproductive Influence following oral royal jelly administration on postpartum ewes. Egyptian Journal of Basic and Applied Sciences, 7(1),7-35.

Pavel, C.I., Mărghitaș, L.A.l., Bobiş, O., Dezmirean, D.S., Şapcaliu, A., Radoi, I., Mădaș, M.N. (2011). Biological Activities of Royal Jelly - Review. Scientific Papers Animal Science and Biotechnologies, 44(2), 108-118.

Pérez, R.E., Rivas, A.R., Sosa, P.G., Cortez, R.C., Pérez, H.P., Gallegos-Sánchez, J. (2014). Administración de jalea real durante la sincronización de estros en ovejas de pelo. XVIII Congreso Internacional de Ovinocultura Congreso Nacional Caprino, Puebla. pp. 310-313.

Pérez-Ruiz, E., Fraire-Cordero, S., Salazar-Ortiz, J., Cortez-Romero, C., Gallegos-Sánchez, J. (2018). Reinicio de la actividad reproductiva en ovejas Pelibuey con control del amamantamiento y administración de jalea real. En Avances de la investigación sobre producción animal y seguridad alimentaria en México. Primera edición. Morelia, Michoacán, México 2018. pp. 363-367.

Pérez-Ruiz, E., Salazar-Ortiz, J., Cortez-Romero, C., Vaquera-Huerta, H., Gallegos-Sánchez, J. (2015). Respuesta reproductiva de ovejas de pelo tratadas con jalea real durante un protocolo de sincronización de estros. XLII Reunión Científica de Asociación Mexicana de Producción Animal y Seguridad Alimentaria. A. C. (AMPA). Montecillo, Texcoco, Estado de México. pp. 16-19.

Scaramuzzi, R.J., Campbell, B.K., DowningJ.A., Kendall, N.R., Khalid, M., Muñoz-Gutiérrez, M., Somchit, A. (2006). A review of the effects of supplementary nutrition in the ewe on the concentrations of reproductive and metabolic hormones and the mechanisms that regulate folliculogenesis and ovulation rate. Reproduction Nutrition Development, 46(4), 339-354. Doi: 10.1051/rnd:2006016

Sosa-Pérez, G., Pérez-Ruiz, E., Pérez-Hernández, P., Cortez-Romero, C., Gallegos-Sánchez, J. (2017). Administración endovenosa de Jalea Real en la actividad ovárica y tasa ovulatoria de ovejas Pelibuey. Agroproductividad, 10(2), 42-46. 